American University Washington College of Law

Digital Commons @ American University Washington College of

Law

Working Papers

Works

$7-2020$

The Failure to Grapple with Racial Capitalism in European

Constitutionalism

Fernanda Giorgia Nicola Dr.

Follow this and additional works at: https://digitalcommons.wcl.american.edu/fac_works_papers

Part of the Constitutional Law Commons, and the European Law Commons 


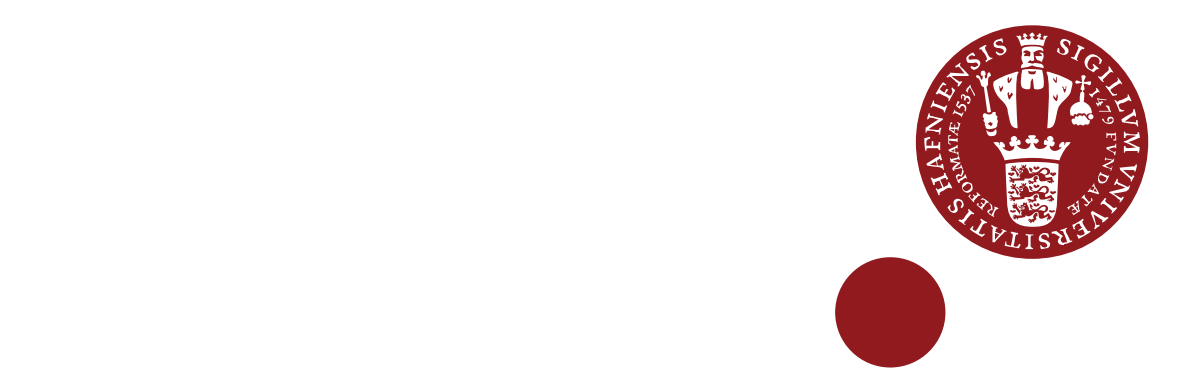

\title{
iCourts
}

iCourts Working Paper Series, No. 201, 2020

IMAGINE Paper No. 8

\section{The Failure to Grapple with Racial Capitalism in European Constitutionalism}

\author{
The First IMAGINE Workshop \\ Jeffrey Miller \& Fernanda Nicola \\ iCourts - The Danish National Research Foundation's \\ Centre of Excellence for International Courts
}

July 2020 


\section{Abstract:}

Since the 1980s prominent scholars of European legal integration have used the example of U.S. constitutionalism to promote a federal vision for the European Community. These scholars, drawing lessons from developments across the Atlantic, concluded that the U.S. Supreme Court had played a key role in fostering national integration and market liberalization. They foresaw the possibility for the European Court of Justice (ECJ) to be a catalyst for a similar federal and constitutional outcome in Europe. The present contribution argues that the scholars who constructed today's dominant European constitutional paradigm underemphasized key aspects of the U.S. constitutional experience, including judgments that favored states' rights doctrines that buttressed the social plagues of slavery and laissez faire policies that reinforced economic inequality. This selective reception of the U.S. experience, bracketing racial subordination and neoliberal policies under the rubric of states' rights, propelled European constitutionalism into a neverland —one that claimed to draw inspiration from U.S. constitutionalism, while simultaneously dismissing as irrelevant some of its most profound socio-economic challenges. This is important, we argue, because the dominant European constitutional paradigm not only provides a distorted picture of U.S. constitutionalism, but also inhibits a deeper understanding of the European one due to its inability to grapple with racial capitalism, embedded both in its colonial past and its present ECJ antidiscrimination jurisprudence.

KEYWORDS: European constitutional imaginaries, Racial capitalism, Comparative Federalism, U.S. Supreme Court, European Court of Justice, Constitutional History, Slavery and Economic Inequality.

Jeffrey Miller is an assistant professor of business at Gallaudet University (Washington DC, USA) and a project manager at the Academy of European Law, European University Institute (Florence, Italy).

Fernanda Nicola is Professor of Law at American University, Washington College of Law, Director of the Program of International Organizations, Law and Development; Permanent Visiting Professor at iCourts

Emails: fnicola@american.edu; jeffrey.miller@eui.eu

IMAGINE has received funding from the European Research Council (ERC) under the European Union's Horizon 2020 research and innovation programme (grant agreement No 803163). 
The iCourts Working Paper Series is funded by the Danish National Research Foundation Grant no. DNRF105.

iCourts - Centre of Excellence for International Courts - focuses on the ever-growing role of international courts, their place in a globalizing legal order, and their impact on politics and society at large. To understand these crucial and contemporary interplays of law, politics, and society, iCourts hosts a set of deeply integrated interdisciplinary research projects on the causes and consequences of the proliferation of international courts.

iCourts opened in March 2012. The centre is funded by a large grant from the Danish National Research Foundation (for the period 2012-18). 


\title{
The Failure to Grapple with Racial Capitalism in European Constitutionalism
}

\author{
Jeffrey Miller ${ }^{1}$ and Fernanda Nicola ${ }^{2}$ C
}

The paper was written as part of a workshop organized in the framework of the Project IMAGINE, which has received funding from the European Research Council (ERC) under the European Union's Horizon 2020 research and innovation programme (grant agreement No 803163).

\begin{abstract}
Since the 1980s prominent scholars of European legal integration have used the example of U.S. constitutionalism to promote a federal vision for the European Community. These scholars, drawing lessons from developments across the Atlantic, concluded that the U.S. Supreme Court had played a key role in fostering national integration and market liberalization. They foresaw the possibility for the European Court of Justice (ECJ) to be a catalyst for a similar federal and constitutional outcome in Europe. The present contribution argues that the scholars who constructed today's dominant European constitutional paradigm underemphasized key aspects of the U.S. constitutional experience, including judgments that favored states' rights doctrines that buttressed the social plagues of slavery and laissez faire policies that reinforced economic inequality. This selective reception of the U.S. experience, bracketing racial subordination and neoliberal policies under the rubric of states' rights, propelled European constitutionalism into a neverland-one that claimed to draw inspiration from U.S. constitutionalism, while simultaneously dismissing as irrelevant some of its most profound socioeconomic challenges. This is important, we argue, because the dominant European constitutional paradigm not only provides a distorted picture of U.S. constitutionalism, but also inbibits a deeper understanding of the European one due to its inability to grapple with racial capitalism, embedded both in its colonial past and its present ECJ antidiscrimination jurisprudence.
\end{abstract}

${ }^{1}$ Project Manager, Academy of European Law (Florence, Italy). PhD European University Institute (Florence, Italy). J.D. American University, Washington College of Law.

2 Professor of Law at American University, Washington College of Law, Director of the Program of International Organizations, Law and Development; Permanent Visiting Professor at iCourts. We would like to thank for their invaluable comments on this paper Jan Komárek, Daniela Caruso, Mathias Möschel and Brishen Rogers. Errors are ours only. 


\section{Table of Contents}

Introduction

PART I The Legacy of Eric Stein in Constructing the European Vision of U.S. Constitutionalism

1. Judicial Supremacy: From the Marshall to the Warren Court

2. Stein's Strategic Omission of States' Rights

PART II Mauro Cappelletti and Joseph Weiler's Vision of Judicial Review

1. Nentral Judicial Review as Liberal Legalism

2. Downplaying the States' Rights jurisprudence of the Rehnquist Court

PART III The Adverse Consequences of Europe's Dominant Constitutional Paradigm

1. The Suppression of Racial Capitalism in European Constiutionalism

2. The Shortcomings of EU Anti-Racist Legislation

Conclusion 


\section{Introduction}

This article provides a critical analysis of EU-U.S. comparative constitutional research. While the EU-U.S. comparison provided a fertile meeting ground during the Cold War for scholars interested in questions involving the rule of law, separation of powers, and federalism, it was also a minefield due to the tainted history of slavery at the heart of the U.S. Constitution. ${ }^{3}$ At a time when France and Belgium were still colonial powers, rather than compare the history of slavery in the U.S. with the history of European colonialism, the founders of the European integration project promoted the idea of a tabula rasa or "clean slate" narrative after the horrors of the Nazi regime. ${ }^{4}$ By the 1960s, scholars viewed the newly-formed European Economic Community as a break from, rather than a partial continuation of, Nazism, Fascism and colonialism. ${ }^{5}$

U.S. constitutionalism may have supplied "a common vocabulary for the language of European integration" and a "conceptual toolbox" to understand the ECJ's rulings. ${ }^{6}$ But on the whole, European legal scholarship has shown a much greater interest in borrowing abstract concepts and terminology than in studying the less-than-pristine ways in which these concepts have been put to practical use in the United States. As a result, while U.S. jurists have had to come to terms with the

${ }^{3}$ See Michael Klarman, The Framers' Coup (2016), and for a more generous reading, Sean Wilents, No PROPERTY IN MAN (2019).

${ }^{4}$ See Kaius Tuori, Empire of Law: Nazi Germany, Exile Scholars and the Battle for the Future of Europe 1, 8 (forthcoming, 2020) (arguing that legal scholars, especially ones in exile after WWII, "wrote about the Europe of law as a hope and aspiration, arguing for the language of the rule of law, rights and reason against the language of blood and culture embraced by the nationalistic and totalitarian regimes such as Nazi Germany"). See also JAMES WHITMAN, HitLER's AMERICAN MODEL (2017) (showing how Nazi racial laws has been themselves inspired by American race laws and racial capitalism).

${ }^{5}$ See Darker Legacies of Law in Europe. The Shadow of National Socialism and Fascism over Europe and its Legal Traditions (Christian Joerges and Navraj Singh Ghaleigh, eds. 2003); Peo Hansen, Stefan JoNSSON EuRAFrica, THE UnTOLD History OF EUROPEAN INTEGRATION AND COLONIALISM (2014).

${ }^{6}$ Giuseppe Martinico, Reading the Others: American Legal Scholars and the Unfolding European Integration, 11 EuR. JL REFORM 35 (2009). 
concept of racial capitalism ${ }^{7}$ and with the failure of the separate-but-equal doctrine, ${ }^{8}$ scholars of European integration have shied away from tracing the connection of populist movements and white supremacist ideologies to Europe's colonial past and capitalist foundations. This is important, we argue, because only by shedding light on Europe's history of colonialism and racial differentiation inherent to capitalism can the project of integration continue towards a more inclusive, equal, and democratic constitutional settlement. ${ }^{9}$

Our contribution shows how influential scholars of European legal integration such as Eric Stein, Mauro Cappelletti, and Joseph H.H. Weiler provided important bridges between the two continents, but also contributed to the reproduction of a liberal legalist understanding of the evolution of U.S. federal judiciary power as a neutral one. As a consequence, the dominant European constitutional law paradigm tends to marginalize the role of U.S. states' rights movements connected to racial subordination and economic inequality in the shaping of U.S. federalism. A liberal legalist perspective, which places considerable confidence in the ability of judges to make wise decisions for the betterment of society, ${ }^{10}$ tends to downplay the fact that judicial law-making can lead (and has led) to the protection of slavery, the endorsement of segregation, and the entrenchment of laissez faire and neoliberal policies_-all with the imprimatur of the U.S. Supreme Court's judicial review power. ${ }^{11}$

This shortcoming runs in parallel with European law scholarship's under-appreciation of the role of Europe's colonial past and a failure to grapple with racial capitalist dynamics that reinforced ethnic

${ }^{7}$ See Oliver Cox, Caste, Class, \& Race; A Study in Social Dynamics (1948) defining racial antagonism as part of the class struggle, because it developed within the capitalist system as one of its fundamental traits. Cox explained how: "Our hypothesis is that racial exploitation and race prejudice developed among Europeans with the rise of capitalism and nationalism, and that because of the world-wide ramifications of capitalism, all racial antagonisms can be traced to the policies and attitudes of the leading capitalist people, the white people of Europe and North America." (Kindle Locations 8327-8329) and for a full analysis of Cox's book see http:/www.racismreview.com/blog/2011/12/21/capitalism-and-racism-remembering-the-great-oliver-c-cox/.

${ }^{8}$ See Nicholas Guyatt, Bind Us Apart: How Enlightened Americans Invented Racial SegRegation (2019).

${ }^{9}$ See Aimee Cesar, Discourse on Colonialism (1972).

${ }^{10}$ See Laura Kalman, The Strange Career of Legal Liberalism (1996).

${ }^{11}$ This partial reception of the U.S. constitutional experience in Europe helps to explains why scholars, judges, and civil servants did not seriously engage with questions of states' rights, slavery and equal protection jurisprudence in the 
differentiations within the Community. ${ }^{12}$ While formally ending colonialism, the European founding fathers were also "securing its continuation" 13 by protecting and encasing new trade and investment regimes between the Community and its former colonies. ${ }^{14}$ This aspect of the evolution of European law is incongruent with the image of the Community as a tabula rasa and has received only limited attention by lawyers. However, after the 2008 financial crisis which led to blaming the "lazy" Greeks and letting the "industrious" Germans have a final say on the European Central Bank's bailouts, the fiction of eliminating ethnicities in the European Union has instead reinforced new forms of racisms ${ }^{15}$ and market hierarchies ${ }^{16}$ which are well-entrenched in European racial capitalism. ${ }^{17}$

We do not intend to suggest, implicitly or otherwise, that a closer reading of U.S. legal history would provide scholars with a clear roadmap out of the EU current legal crises. The U.S. Supreme Court most certainly has not discovered the "magic bullet" that definitively settles the tension between local and federal powers, overcomes the legacy of white supremacy, or manages to fully grapple with racial capitalism. ${ }^{18}$ Our contention is considerably more modest; namely, that the unvarnished record provides

multi-volume InTEGRation through LAw Europe AND the AMERICAN FEDERAL EXPERIENCE (MAURO CAPPELLETTI, MONICA SECCOMBE AND JOSEPH H. H. WEILER EDS. 1986).

${ }^{12}$ Cedric J. Robinson, The Making of the Black Radical Tradition (1983) explaining its legacy as "Capitalism was "racial" not because of some conspiracy to divide workers or justify slavery and dispossession, but because racialism had already permeated Western feudal society. The first European proletarians were racial subjects (Irish, Jews, Roma or Gypsies, Slavs, etc.) and they were victims of dispossession (enclosure), colonialism, and slavery within Europe. Indeed, Robinson suggested that racialization within Europe was very much a colonial process involving invasion, settlement, expropriation, and racial hierarchy.” Boston Review here

\section{${ }^{13}$ See Peo Hansen, Stefan Jonsson Eurafrica, supra note 5 [showing how the project of "Eurafrica" was very much alive during the Treaty of Rome negotiations] (1955-7).}

${ }^{14}$ See QuinN Slobodian, Globalists (2018).

15 See Dimitry Kochenov, Citizenship (MIT 2019); Ugo Mattei And Laura Nader, Plunder: When the Rule of LAW IS ILLEGAL (2008).

${ }^{16}$ See Damjan Kukovec, Economic Law, Inequality and Hidden Hierarchies on the EU Internal Market, 38 Michigan Journal of International Law (2016).

${ }^{17}$ See Walter Johnson, To Remake the World Slavery, Racial Capitalism, and Justice from Boston Review (2018) http://bostonreview.net/forum/walter-johnson-to-remake-the-world.

18 Despite the achievements of the Warren Court against racial discrimination, critical race scholars have provided important critiques of its Brown legacy. DerRick Bell, Silent Covenants: Brown V. BoARd of EdUCATION AND the UNFULFILLED HOPES FOR RACIAL REFORM (2005). Today racial discrimination persists, especially against black men that come into contact with the criminal justice system. See Angela Davis, Policing the Black Man: Arrest, 
scholars with more useful insights than the selective version of U.S. constitutionalism that prevails in much European legal discourse.

In Part I we turn our attention to the reception of U.S. constitutionalism in Europe. The journey begins with Eric Stein's contribution to the study of European Community law and narrates how he became, through his strategic friendship with Michel Gaudet, the director of the Commission's Legal Services, ${ }^{19}$ a supporter of expanding the powers of the ECJ. Stein promoted an ambitious judicial constitutional project for Community law in the footsteps of the Warren Court. Stein's approach also set aside some of the U.S. Supreme Court's most infamous rulings, ${ }^{20}$ which still haunt the Court to this day. ${ }^{21}$ Because of

Prosecution, And Imprisonment (2019). In the New Jim Crow, Michelle Alexander powerfully demonstrated the pernicious effects of discrimination with respect to laws concerning convicted criminals and the war on drugs. See Michelle Alexander, New Jim Crow: Mass Incarceration in the Age of Colorblindness (2010) and how the U.S. still remains in deep denial of this situation, The Injustice of this Moment is Not an "Aberration" (NYT 17 of January 2020). In a similar way, Paul Butler shows how racial injustice continues to persevere in the criminal justice system. See Paul Butler, Chokehold: Policing Black Men (The New Press, 2017). Among comparative lawyers, James Whitman has traced, through an intellectual and sociological history of the concept of dignity, the great disparity between U.S. and European treatment of criminal offenders, which has resulted in the well-known disenfranchisement of civil rights and liberties of large numbers of African-Americans. See JAmes Q. Whitman, Harsh Justice: Criminal Punishment and the Widening Divide Between America And Europe (2003).This literature shows with piercing clarity that despite the achievements vis-à-vis anti-discrimination law, the U.S. constitutional experience, especially when it comes to the criminal justice system, continues to have a disproportionally adverse impact on black lives. See Alicia Garza, A History of the \#BlackLivesMatter Movement, The Feminist Wire. Retrieved October 15, 2015; PATRISSE KHANCullors, When They Call You a Terrorist: A Black Lives Matter Memoir (2018).

19 Julie Bailleux, Michel Gaudet a law entrepreneur: the role of the legal service of the European executives in the invention of EC Law and of the Common Market Law Review, Vol. 50, No. 2; CommON MARKET LAW REVIEW, pp. 359-367 (2013).

${ }^{20}$ See Dred Scott v. Sandford, 60 U.S. 393 (1857) (In an opinion written by Justice Taney the majority held that "a negro, whose ancestors were imported into [the U.S.], and sold as slaves," whether enslaved or free, could not be an American citizen and therefore did not have standing to sue in federal court.); See also Korematsu v. United States, 323 U.S. 214 (1944) (ruling that the evacuation order violated by Korematsu was valid. The majority found that the Executive Order did not show racial prejudice but rather responded to the strategic military imperative of the President.).

${ }^{21}$ See Trump v. Hawaii 138 S. Ct. 2392 (2018) (commonly referred to as the "Travel Ban case"); Robert Tsai, How Activists Resisted — and Ultimately Overturned — an Unjust Supreme Court Decision, WASHINGTON Post,(Jan. 30, 
the deep synergies between states' rights and segregation policies supported by white supremacist ideologies in the U.S., Stein's reluctance to engage with national resistances to federal power in Europe is perhaps understandable, but it had the consequence of presenting a rather skewed image of U.S. constitutional law practice.

Part II focuses on the European reception of U.S.-style federal judicial review, and in particular on its liberal legalist understanding through the influential works of Mauro Cappelletti and Joseph H. H. Weiler. Because of what Duncan Kennedy calls the "legitimation effect, ${ }^{, 2}$ scholars of European integration still promote judicial review as a neutral instrument in the hands of supranational judges dedicated to the protection of individual rights and the resolution of quasi-federal conflicts based on institutional competence arguments rather than the very interests they are contending within it. ${ }^{23}$ Frequently underestimated in European legal scholarship are the periods when the U.S. federal judicial power promoted racial segregation, ${ }^{24}$ did not adequately protected minority rights through equal protection doctrines $^{25}$ or endorsed freedom of contract to entrench laissez faire policies. ${ }^{26}$ In the mid-1980s, the resurgence of states' rights jurisprudence with the new federalism of the Rehnquist Court altered market

2018) https://www.washingtonpost.com/outlook/2019/01/30/how-activists-resisted-ultimately-overturned-an-unjustsupreme-court-decision/?utm_term=.4faf093aa696.

${ }^{22}$ DunCAn KenNedy, A CRitique of AdJudication, Fin DE SiÈCle) (1997) [explaining how the legitimation effect in judicial law making is the attitude about social reality that the desirability for radical social change is replaced by a moderate reformist one.]

${ }^{23}$ Id. p. 252 [showing how federalism meant the 'withdrawal' of the allocation of federal or state power form the political discussion].

${ }^{24}$ See Plessy v. Ferguson, 163 U.S. 537 (1896) [in which the U.S. Supreme Court upheld the constitutionality of racial segregation laws for public facilities as long as these were "separate but equal"].

${ }^{25}$ See Washington v. Davis, 426 U.S. 229 (1976), [the Supreme Court held that that laws having a racially discriminatory effect but with a racially discriminatory purpose are valid under the Fourteenth Amendement].

${ }^{26}$ See Lochner v. New York, 198 U.S. 45 (1905) in which the Supreme Court held that a New York law limiting the working hours for bakers violated the Fourteen Amendment of the U.S. Constitution. 
deregulation through limits to the Commerce Clause. ${ }^{27}$ This new line of states' rights jurisprudence was once again downplayed by European legal scholars focusing on U.S. constitutionalism. ${ }^{28}$

In Part III, we turn our attention to the consequences of setting aside the aspects of the U.S. federal experience, such as states' rights, that were synonymous with racial subordination and the entrenchment of economic inequalities. In either form, the constitutional doctrines of states' rights were deemed irrelevant by scholars of European legal integration due to the fact that the "clean slate" narrative could overcome racial subordination as ethnic differentiation characterizing the European Community. As powerfully described in Aimé Cesar's Discourse on Colonialism, most scholars of European integration have avoided the obvious comparison between the U.S. legitimation of slavery and the colonial and white supremacist ideologies at the root of the "Europe of Adenauer, Schuman and Bidault." 29 In this way, scholars unable to come to terms with racial capitalism could construe a European constitutional utopia in which the "Echoes of Empire" that were present since the Schuman declaration have been suppressed. ${ }^{31}$

${ }^{27}$ United States v. Lopez, 514 U.S. 549, 549 (1995) (holding that the Federal Gun Free Zone Act of 1990 exceeded Congress' authority under the commerce clause).

${ }^{28}$ See Daniela Caruso, E.U. Law in U.S. Legal Academia, 20 Tulane J. Int'l \& Comp. L. 175, 182 (2011) [showing that the 1990s' interest of some U.S. constitutionalist scholars in the dynamics of European integration was partly due to the 'Rehnquist effect' - i.e. to the fact that Europe's seemingly apolitical federalism could shield the Rehnquist Court from its critics.]

${ }^{29}$ See Aimee Cesar, Discourse on Colonialism (1972) p. 37.

${ }^{30} \mathrm{See}$ Echoes of EmPIRE: Memory, Identity and Colonial Legacies (Kalypso Nicolaidis, Berny Sebe \& Gabrielle Maas eds., 2015).

${ }^{31}$ See Peo Hansen \& Stefan Jonsson, Euroafrica Incognita: The Colonial Origins of the European Union, History of the Present, 7 History of the Present, 1, 1-32 (2017). 


\section{The Legacy of Eric Stein in Constructing the European Vision of U.S. Constitutionalism}

1. Judicial Supremacy: From the Marshall to the Warren Court

We begin with Eric Stein, author of the seminal article, Lawyers, Judges, and the Making of a Transnational Constitution, ${ }^{32}$ and the person widely regarded as the main figure responsible for the "leading paradigm on the nature of European law." ${ }^{\prime 3}$ In his 1981 essay, Stein argued that the ECJ had interpreted the Founding treaties "in a constitutional mode rather than employing the traditional international law methodology."

34 As Boerger has shown in her extensive research, Stein's life experiences are relevant to his approach to U.S. constitutional law doctrines and how he applied these concepts to analyze Community law.

Stein was born in 1913 into a Jewish family in Holice, a small town east of Prague, in the then-AustroHungarian Empire. He received a classical civil law education at Charles University in Prague and was subsequently drafted into the Czech army. He served in the Czech infantry until March 1939, when the Nazis took control of the country and dissolved the Czech military. Stein fled Czechoslovakia in August 1939 and, after a harrowing journey, arrived in New York at the age of 26. In 1942, with financial assistance from his relatives, he graduated with a J.D. from the University of Michigan, and then proceeded to enlist in the U.S. army. In 1946, Stein joined the U.S. State Department's newly formed Bureau of the United Nations, where he advised U.S. representatives to the UN General Assembly and UN Security Council for nine years.

Stein followed the European integration process from its earliest days. His article, The European Coal and Steel Community: The Beginning of Its Judicial Process, was the first English-language publication on the topic. In the same year (1955), he joined the faculty of the University of Michigan Law School. As Boerger

\footnotetext{
${ }^{32}$ Eric Stein, Lawyers judges and the Making of a Transnational Constitution, 75 AMERICAN JOURNAL OF INTERNATIONAL LAW, 1-27 (1981).

${ }^{33}$ Anne Boerger, At the Cradle of Legal Scholarship on the European Union: The Life and Early Work of Eric Stein, 62 THE AMERICAN JOURNAL OF COMPARATIVE LAW 859, 861 (2014).

${ }^{34}$ Eric Stein, Lawyers, Judges, and the Making of a Transnational Constitution, 75 AMERICAN JOURNAL OF INTERNATIONAL LAW 1, 1 (1981).
} 
explains, Stein's turn to European law coincided with his dissatisfaction with the potential of international law to ensure world peace. ${ }^{35}$

In A Quiet Revolution, ${ }^{36}$ Weiler, who became a law professor at the University of Michigan "thanks in part to the unconditional support of Stein", ${ }^{37}$ observed that the intellectual voyage from international law to EC law was typical for the first generation of scholars of European integration. ${ }^{38}$ The Cold War was an inauspicious period for the construction of an international legal system. By contrast,

\begin{abstract}
"Community law and the ECJ were everything that an international lawyer could dream about: The Court was creating a new order of international law in which norms were norms, sanctions were sanctions, courts were central and frequently used ... Community law, as transformed by the ECJ, was an antidote to the international legal malaise." 39
\end{abstract}

Stein's path-breaking re-conceptualization of Community law continues to influence EU legal scholarship to this day, but his work was by no means neutral or detached. For very understandable reasons, Stein

${ }^{35} I d$. at 869 (“. . . Stein had grown deeply disillusioned by the shortcomings of the United Nations, which by then had proved incapable of unifying the world under the rule of law. Like others in the immediate postwar years, Stein had initially embraced his job at the Bureau of the United Nations with some sort of missionary zeal and the hope that the new organization would prevent conflicts and atrocities similar to ones that had just destroyed his own family. When the Cold War set in and prevented any progress, he grew increasingly frustrated. As he recalled much later, he was however 'not [yet] prepared to accept the idea that law and institutions were irrelevant in the international system.' As a result, studying the innovative legal and institutional developments in Europe somehow offered an attractive alternative, fulfilling both his need to help build a more united world and his tacit but deeply-rooted desire to keep in touch with his European background.") (internal citations omitted).

${ }^{36}$ Joseph H. H Weiler, A Quiet Revolution: The European Court of Justice and its Interlocutors, 26 COMPARATIVE Political StUdies 510-34 (1994).

${ }^{37}$ Anne Boerger, At the Cradle of Legal Scholarship on the European Union: The Life and Early Work of Eric Stein, 62 THE AMERICAN Journal OF COMPARATIVE LAW 859, 889 (2014).

${ }^{38}$ The scholarly shift from international law to European Community law was a common route, but not the exclusive one. The early generation of European Community lawyers also included researchers from the fields of business law, private international law, and comparative law. Our thanks to Jan Komárek for this helpful comment.

${ }^{39}$ Id. at $530-31$. 
had a clear vision of what he wanted the Community to become. And for the Community to achieve its potential as a peace-enhancing alternative to international law, it was essential that the ECJ gain power over state sovereignty and establish itself as the unquestioned highest authority in its jurisdiction.

Stein's image of an authoritative and centralized supreme court appears to be heavily influenced by the nineteenth century jurisprudence of Chief Justice John Marshall. ${ }^{40}$ In the 1803 case of Marbury v. Madison, the Marshall Court established the principle of judicial review, which empowered it to strike down federal legislation that conflicted with the U.S. Constitution. ${ }^{41}$ In McCulloch v. Maryland, the Supreme Court ruled that a state tax levied on a federal bank incorporated by the government under the Necessary and Proper Clause was unconstitutional. ${ }^{42}$ In Martin v. Hunter Lessee, ${ }^{43}$ Justice Story justified through popular sovereignty the Supreme Court's judicial authority to strike down unconstitutional state laws to maintain national uniformity. In these, and many lesser-known decisions consolidating federal judicial supremacy, ${ }^{44}$ advocates for states' rights, thanks to a cautiously interventionist Supreme Court, suffered a series of setbacks. $^{45}$

The philosophy of natural law deeply influenced the drafters of the U.S. Constitution. ${ }^{46}$ In Federalist 78, Hamilton provided a very convincing picture of the federal courts as institutions without a "will" and composed of a body of independent judges, professionally trained with life-tenure appointments. The

${ }^{40}$ John Marshall served as the Chief Justice of the U.S. Supreme Court from 1801-1835. During Marshall's tenure, the power and prestige of the U.S. Supreme Court grew considerably. Today Chief Justice Marshall's record has been reconsidered in upholding the institution of slavery, see PAUl FINKELMAN, SUPREME InJUSTICE: SLAVERY IN THE NATION’s Highest COURT (2018).

${ }^{41}$ Marbury v. Madison, 5 U.S. (1 Cranch) 137 (1803).

${ }^{42}$ McCulloch v. Maryland, 17 U.S. (4 Wheat.) 316 (1819) relying on the Necessary and Proper Clause, or elastic clause of Article I, Section 8 of the U.S. Constitution.

${ }^{43}$ See Martin v. Hunter Lessee, 14 U.S. (1 Wheat.) 304 (1816).

${ }^{44}$ See Chisholm v. Georgia and Barron v. Baltimore [ Chief Justice Marshall's cautious attempt to address the nationstate relationship in favor of a "consolidated national union." McCloskey p. 22] and for a comparison between this early SCOTUS jurisprudence and the ECJ see Leslie F. Goldstein, Constituting Federal Sovereignty: The EUROPEAN UNION IN COMPARATIVE CONTEXT (2001).

\footnotetext{
${ }^{46}$ Edward S. Corwin, The "Higher Law" Background of American Constitutional Law, 42 HARV. L. REV. $365-409$
} (1929). 
Founding Fathers' emphatic affirmation of the principles of fundamental law gave the Constitution, as Robert McCloskey put it, its "odor of sanctity" and allowed the Supreme Court to assume a "priestly mantle." 47 The "least dangerous branch," according to Hamilton, was exactly what Chief Justice Marshall was planning to achieve in Marbury v. Madison. In establishing the power of judicial review of the U.S. Supreme Court, the justices interpreted the U.S. Constitution within the boundaries established by fundamental law. But in practice, they too carried out their obligations within the boundaries of what "popular opinion would tolerate." 48 The justices knew very well they could not become completely detached from what the people would accept.

The other more recent influence on Stein was the legacy of the Warren Court (1953-1969), led by the progressive former California governor Chief Justice Earl Warren. ${ }^{49}$ By the time Stein had received his law degree, the U.S. Supreme Court had long overruled its laissez faire jurisprudence ${ }^{50}$ and the New Deal settlement had allowed newly elected justices to grant Congress greater leeway to regulate market activities, going as far as authorizing federal regulation of wheat grown on a local farm for local consumption. ${ }^{51}$ While limiting its judicial scrutiny for individual economic rights, ${ }^{52}$ in 1938 the Carolene Products Court, in its famous footnote four, suggested it would undertake more rigorous judicial scrutiny when the civil liberties or civil rights of minorities were threatened due to an inability to access equal benefits. $^{53}$

${ }^{47}$ Robert G. McCloskey, The AmErican Supreme Court, p. 8 (revised by Sanford Levinson, 6th ed. 2006).

${ }^{48}$ Id. at 9.

49 See lucas A. PoWe JR, Warren Court And American Politics (2001); G. EdWARd White, EARL Warren: A Public Life (1982). Morton Horwitz, The WarRen Court ANd the Pursuit of Justice (1999)_ Ed Cray, Chief Justice: A Biography of EARL WARREN_(2008).

${ }^{50}$ See Nebbia v. New York, 291 U.S. 502 (1934).

${ }^{51}$ See Wickard v. Filburn, 317 U.S. 111 (1942), and for a critical view of the elitist judicial supremacy created by the Warren Court at the expense of popular constitutionalism, see Larry D. Kramer, Foreword, We the Court, 115 Harvard. L. Rev. 5, 122 (2001); see generally, LuCAS A. Powe JR, WARren CourT AND AMERICAN Politics (2001) p. 5-6.

52 West Coast Hotel v. Parrish 300 U.S. 379 (1937) [The Supreme Court upheld a minimum wage law for women holding that liberty of contract a subset of liberty that could be limited by public interest.]

${ }^{53}$ See United States v. Carolene Products Company, 304 U.S. 144 (1938). 
When Stein began his career at Michigan Law school, the U.S. Supreme Court "was a Court of godsBlack, Douglas, Warren—hurling thunderbolts to start our cultural revolutions." ${ }^{54}$ In 1954, in Brown v. Board of Education, Chief Justice Warren famously affirmed, "in the field of public education the doctrine of 'separate but equal' has no place." ${ }^{55}$ In Gideon $v$. Wainwright, Warren worked hard behind the scenes to reach another unanimous ruling that required States under the Sixth Amendment to provide the right to counsel to defendants who were unable to afford a lawyer in criminal cases. ${ }^{56}$ In Warren's five to four Miranda v. Arizona majority opinion, the Court held that the Fifth Amendment required that law enforcement officials advise suspects of their right to remain silent and to obtain an attorney during interrogations while in police custody. ${ }^{57}$ Finally in 1967, Warren wrote another unanimous opinion, Loving v. Virginia, that struck down a state law prohibiting inter racial marriage in violation of the Equal Protection and Due Process clause of the Fourteenth Amendment. ${ }^{58}$ Such jurisprudence was rightly praised for rendering illegitimate the prevalent mechanisms and practices of racial discrimination. In retrospect, critical race scholars like Derrick Bell have shown the failures for black youths of the judicial integrationist ideal, ${ }^{59}$ while Sheila Foster pointed out how the notion of "racial agency" was "lost in the translation of specific claims of racial injustice into abstract constitutional principle." ${ }^{\prime \prime}$

Living, as Stein did, through a period when the Warren Court made marked advances in "the constitutional guarantee of equality between races, between voters, and between criminal defendants, ${ }^{61}$ it is not surprising that he invested much of his considerable intellectual and organizational talents in

\footnotetext{
${ }^{54}$ See https://newrepublic.com/article/104659/warren-court-children.

${ }^{55}$ Brown v. Board of Education, 347 U.S. 483 (1954).

${ }^{56}$ Gideon v. Wainwright, 372 U.S. 335 (1963). See Yale Kamisar, How Earl Warren's Twenty-Two Years in Law

Enforcement Affected His Work as Chief Justice, 3 OHIO ST. J. CRIM. L. 11-32 (2005)

${ }^{57}$ Miranda v. Arizona, 384 U.S. 436 (1966).

${ }^{58}$ Loving v. Virginia, 388 US 1 (1967).

${ }^{59}$ Derrick A. Bell, Jr., Serving Two Masters: Integration Ideals and Client Interests in School Desegregation Litigation, 85 YALE L.J. 470 (1976).

${ }^{60}$ See Sheila Foster, Race, Agency, and Equal Protection: A Retrospective on the Warren Court in EARL WARREN and the Warren Court: The Legacy in AMERICAN ANd Foreign Law, Harry n. Scheiber ed. (2007).

${ }^{61}$ See William F. Swindler, The Warren Court: Completion of a Constitutional Revolution, 23 VAND. L. REv. 205, 206 (1969).
} 
pursuit of the "constitutionalization" of European Community law and the expansion of judicial supremacy while omitting the tainted history of the states' rights and popular sovereignty jurisprudence. ${ }^{62}$

\section{Stein's Strategic Omission of States' Rights}

The delegates who drafted the U.S. Constitution are often celebrated for producing a document that managed to win the support of a diverse group of states and statesmen, but as McCloskey memorably puts it: "this congenial result had been achieved not only by compromise but by forbearance." ${ }^{93}$ Indeed, the U.S. Constitution was so open-ended that genuine uncertainty existed in 1790 as to whether the document had created a league of sovereign states or a new nation. As states' rights advocates repeatedly stressed from the period of the Marshall Court onward, had the Founding Fathers intended for the U.S. Supreme Court to wield a tool as powerful as judicial review, it is odd that they should have granted it in such an oblique manner, rather than forthrightly. ${ }^{64}$

In truth, the U.S. Supreme Court's rulings on the relationship between federal and state powers are noncoherent, and they remain politically contested to this day. Legal historians have highlighted how ideological shifts discernable in U.S. constitutionalism tilt it either in favor of a federal plenary power or in favor of states' rights. Thomas Jefferson, the principal author of the Declaration of Independence, ${ }^{65}$

\footnotetext{
${ }^{62}$ For a critical view of the elitist judicial supremacy created by the Warren Court at the expense of popular constitutionalism, see Larry D. Kramer, Foreword, We the Court, 115 HARV. L. REV. 5, 122 (2001) and the more
} cautious response by Robert Post and Reva Siegel, Popular Constitutionalism, Departmentalism, and Judicial Supremacy 92 CAL. L. REV. 1027 (2004).

${ }^{63}$ Robert G. McCloskey, The AmericAn Supreme Court (revised by Sanford Levinson, 6th ed. 2006). As the author explains the Constitution set forth important principles about which there was no serious disagreement among the colonists, but "weightier difficulties that might have prevented ratification were either left severely alone by the Founding Fathers or treated in ambiguous clauses that passed the problems on to posterity."

${ }^{64}$ Id. Explaining that the U.S. Constitution did not clearly provide the U.S. Supreme Court with superior authority over state supreme courts, and a close reading of the text leaves questionable whether the U.S. Supreme Court has the power to strike down national legislative acts inconsistent with the U.S. Constitution.

${ }^{65}$ Melvin I. Urofsky, Thomas Jefferson and John Marshall: What Kind of Constitution Shall We Have? 32 JOURNAL OF SuPREME COURT History 109, 117 (2006) explaining Jefferson as also Chief Justice Marshall's third cousin once 
who was deeply influenced by the French revolutionary experience, was the period's foremost advocate for popular sovereignty. For Jefferson, the states provided the most effective safeguard of the nation's freedoms and self-rule, and the U.S. Supreme Court had shamelessly exceeded its mandate. When the U.S. Supreme Court decided, in Chisholm v. Georgia (1793), ${ }^{66}$ that for the purposes of the Union, "Georgia is not a sovereign state," Congress promptly passed the XI Amendment, which overrode the Court's ruling and placed the states on a stronger footing vis-à-vis the federal courts. ${ }^{67}$ Popular sovereignty acted at the same time as a source of legitimacy and a counterweight to judicial governance.

Surely Stein was well aware of this, but his work hardly explored the Jeffersonian perspective. As Boerger shows, Stein's Bellagio grant to study the role of courts in building common markets became controversial because the "undertaking clearly bore a political overtone." ${ }^{\prime 6}$ Even Stein's friend and wellknown comparative law scholar, Otto Kahn-Freund, began to doubt the scientific method behind Stein's project, which aimed to demonstrate how the highest courts in both the U.S. and Europe represented the most "federalist constitutional organ." ${ }^{69}$ In highlighting the correspondence between these two scholars, Boerger shows that Khan-Freund was worried that Stein would dismiss too easily the “centrifugal forces, the resistances, the great power and the strong case of our 'Jeffersonian' of 1979."”

Indeed, the work of the new European legal historians ${ }^{71}$ has shed light on Jeffersonian attitudes in Europe through national resistances to European legal integration and to ECJ judicial governance, emanating not only from domestic courts, but also from executive branches of governments, diplomatic circles and the

removed and he "went to his grave believing that Marshall and his colleagues on the Supreme Court were evil, a gang . . . hell-bent on sabotaging the republican government from within.".

${ }^{66}$ See Chisholm v. Georgia, 2 U.S. (2 Dall.) 419 (1793) here the Supreme Court held that Article 3, Section 2, of the Constitution abrogated the states' sovereign immunity and granted federal courts the affirmative power to hear disputes between private citizens and states.

${ }^{67}$ Robert G. McCloskey, supra note 65.

${ }^{68}$ Anne Boerger, At the Cradle of Legal Scholarship on the European Union: The Life and Early Work of Eric Stein, 62 THE AMERICAN Journal OF COMPARATIVE LAW 859, 883 (2014).

${ }^{69} I d$. at 884 .

${ }^{70} \mathrm{Id}$.

${ }^{71}$ See Morten Rasmussen, Towards a New History of European Law, 21 CONTEMPORARY EUROPEAN HISTORY, 305-18 (2012). 
media. ${ }^{72}$ For instance, historians have traced the resistance of the Gaullistes in France at odds with Christian Democratic politicians such a Jacques Delors ${ }^{73}$ in their attempt to limit preliminary references to the ECJ ${ }^{74}$ In 1979 the National Assembly had to intervene to require domestic courts to accept the hierarchy of EC law over French national law. ${ }^{75}$ In the Italian and German realms, the resistance was prominent in the early 1970s, spearheaded by Constitutional Court decisions such as Frontini ${ }^{76}$ and Solange, ${ }^{77}$ which asserted the predominance of domestic courts as the ultimate defenders of fundamental rights.

It might be a stretch to equate U.S. popular sovereignty and the states' rights jurisprudence of the U.S. Supreme Court to the early national resistances in EU law. The latter were triggered by national constitutional courts seeking to affirm the relevance of fundamental rights against the $\mathrm{ECJ}^{78}$ and by domestic judiciaries revamping their national legal traditions. ${ }^{79}$ Nevertheless, it appears reasonably clear that Stein was not eager to recognize the legitimacy of the early opposition expressed by political and legal elites to the creation of a supranational legal order. ${ }^{80}$

${ }^{72}$ See Bill Davies, Resisting the European Court of Justice. West Germany's Confrontation with European LAW, 1949-1979 (2012.)

${ }^{73}$ See Alexandre Bernier, La France et le droit communautaire 1958-1981: Histoire d'une réception et d'une coproduction (2018) (Ph.D. dissertation, University of Copenhagen).

${ }^{74}$ Vera Fritz, The First Member State Rebellion? The European Court of Justice and the Negotiations of the 'Luxembourg Protocol' of 1971, 21 EuROPEAN LAW JOURNAL, 680-699 (2015).

${ }^{75}$ Morten. Rasmussen, How to Enforce European Law? A New History of the Battle over the Direct Effect of Directives, 1958-1987, 23 EUROPEAN LAW JOURNAL, 290-308 (2017).

${ }^{76}$ Frontini case, Italian Constitutional Court Sentenza n. 183 (18 December 1973).

${ }^{77}$ Solange I, Internationale Handelsgesellschaft von Einfuhr- und Vorratsstelle für Getreide und Futtermittel, decision of 29 May 1974, BVerfGE 37, 271 [1974].

${ }^{78}$ See Internationale Handelsgesellschaft $\mathrm{mbH}$ v Einfuhr- und Vorratsstelle für Getreide und Futtermittel (Case 11/70), EU:C:1970:114, [1970] and Bill Davies, Internationale Handelsgesellschaft and the Miscalculation at the Inception of the CJEU's Human Rights Jurisprudence, p. 157 in EU LAW STORIES (B. DAVIES AND F. NiCOLA, EDS. 2017).

${ }^{79}$ See Fernanda G. Nicola, National Legal Traditions at Work in the Jurisprudence of the Court of Justice of the European Union, 64 American Journal of COMPARATIVE LAW (2016).

${ }^{80}$ See Morten Rasmussen, Dorte Sindbjerg Martinsen, EU Constitutionalization Revisited: Redressing a Central Assumption in European Studies, 25 European Law Journal (2019). 


\section{Mauro Cappelletti and Joseph Weiler's Vision of Judicial Review}

Part II engages with the contributions of Mauro Cappelletti and Joseph H. H. Weiler to the European image of U.S.-style judicial review. We argue that, in a manner analogous to Stein, who advocated for ECJ supremacy and downplayed U.S. states' rights movements, Cappelletti and Weiler exported to Europe a judicial review utopia—one which drew on the U.S. experience, but side-stepped the political explosiveness that has regularly beset U.S. Supreme Court judicial review in practice. By deploying the fiction of judicial neutrality, European law scholars advanced a more attractive blueprint for European legal integration than the U.S. historical record actually offered.

1. Neutral Judicial Review as Liberal Legalism

In 1971, Cappelletti published Judicial Review in the Contemporary World, a short but highly influential book that traced the spread of judicial review from the United States to much of the rest of the world. ${ }^{81}$ Through his book and later publications, Cappelletti presented judicial review as the ultimate safeguard of fundamental values against majoritarian political institutions. ${ }^{82}$ In a recent publication that builds on and extends Cappelletti's work, Doreen Lustig and Weiler observe that Cappelletti viewed judicial review as an "unqualified public good" 83 and courts "as the most efficient guarantee for the effectiveness and

${ }^{81}$ See, e.g. Mauro Cappelletti, Judicial Review IN THE CONTEMPORARY WORLD (1971) (detailing how judicial review spread from the United States to many countries around the world).

${ }^{82}$ Mauro Cappelletti and David Golay, Judicial Review, Transnational and Federal: Its Impact ON InTEGRATION, EUI Working Paper No. 4. (September 1981).

${ }^{83}$ Doreen Lustig \& Joseph H.H. Weiler, Judicial Review in the Contemporary World-Retrospective and Prospective, 16 INT'L J. CONST. L. 315, 316 (2018). For a critique of this work, see Mila Versteeg, Understanding The Third Wave of Judicial Review: Afterword to the Foreword by Doreen Lustig and JHH Weiler. 17 INT'L J. CONST. L. 1, 10 (2019) (arguing that the authors seem unwilling to seriously entertain the possibility that domestic courts are closely examining international legal norms, not because they are detached, neutral arbiters in search of higher truths, but rather more prosaically, because they are bending to social and political pressure). 
enforcement of' individual rights and liberties. ${ }^{84}$ In Cappelletti's view, the revival of judicial review in Europe was a logical reaction to fascism and World War II, which "demonstrated the horrendous potential for tyranny, even majority tyranny, of governments not subject to constitutional restraint" ${ }^{85}$ Cappelletti readily acknowledged that judicial review was not implemented in the same way in every country, but he identified a cross-European consensus that unchecked parliamentary sovereignty had the potential to pose an existential threat to democratic governance.

Cappelletti was not only a proponent of judicial review in general terms. He also made it quite clear that he saw the ECJ, rather than the Member State courts, as the proper institution to entrust "the ultimate judicial authority in the Community as regards questions of fundamental rights". ${ }^{86}$ In The Transformation of Europe, Weiler weaves a complementary theme into his own work, asserting that the constitutionalization of EU law was undoubtedly aided by "that deep-seated legitimacy that derives from the mythical neutrality and religious-like authority with which we invest our supreme courts". ${ }^{87}$ Faith in the power of judicial review as a superior arbiter defending individual rights or solving institutional conflicts without engaging with the underlying political economy and racial capitalism goes hand-in-glove with faith in the ability of judges to make rulings in a fair and impartial manner.

US legal realism has revealed the untold implications and ideologies disguised under liberal legalism in the rulings handed down during the Gilded Age by a Supreme Court that benefited property owners and business elites united by a common laissez-faire ideology. ${ }^{88}$ Due to its low legitimacy in the aftermath of

\footnotetext{
${ }^{84}$ Doreen Lustig \& Joseph H.H. Weiler, Judicial Review in the Contemporary World-Retrospective and Prospective, 16 INT’L J. CONST. L. 315, 316 (2018).

${ }^{85}$ Mauro Cappelletti and David Golay, Judicial Review, Transnational and Federal: Its ImPact ON InTEGRATION, EUI Working Paper No. 4. (September 1981) at 16.

${ }^{86}$ Mauro Cappelletti and David Golay, Judicial ReVIEw, TrAnSNATIONAL AND FedERAL: ITS IMPACT ON INTEGRATION, EUI Working Paper No. 4. (September 1981) at 79-80.

87 J. H. H. Weiler, The Transformation of Europe 100 YALE L. J., 2403, 2426-30 (1991); Joseph H. H Weiler, A Quiet Revolution: The European Court of Justice and its Interlocutors, 26 COMPARATIVE POLITICAL STUdiEs 510-34 (1994). ${ }^{88} \mathrm{See}$ Marvin B. Becker, The Emergence of Civil Society in the Eighteenth Century: A privileged Moment IN THE History OF ENGLAND, SCOTLAND AND FRANCE (1994).
} 
Dred $S$ cott, ${ }^{89}$ the Supreme Court focused strictly on questions of economic control rather than racial emancipation while endorsing liberal legalism and its abstract legal reasoning. As early as 1873 in the Slaughter-House Cases, ${ }^{90}$ the plaintiffs' lawyers made a creative argument using the XIV Amendment, which was intended to eliminate racial subordination, to instead protect any person against State laws that would "deprive any person of life, liberty and property, without due process of law." 91 The U.S. Supreme Court gradually accepted the liberal notion that liberty of contract was enforceable as an individual right under the due process clause of the Fourteenth Amendment. ${ }^{92}$ A few years later, the U.S. Supreme Court was ready to interpret the notion of freedom of contract as derived directly from Herbert Spencer. ${ }^{93}$ The Court reached the apex of its laissez faire jurisprudence in Lochner v. New York, which held that the freedom of contract was under substantive due process a limit to the valid exercise of states' police powers. ${ }^{94}$ Justice Oliver W. Holmes's dissent rejected the notion of freedom of contract as a displacement of the basic notion that states had the power to regulate the economy. Instead he famously explained that the

${ }^{89}$ Id. and in hindsight Dred Scott seemed stunningly self-destructive. "In the 1850 s the Court enjoyed popular support as nearly unanimous as can ever be expected in a diverse democratic society," notes McCloskey. "Eight years later, it had forfeited that position, and its role in the American polity was nearly negligible.."

${ }^{90}$ See Slaughter-House Cases, 83 U.S. 36 (1873), in which the dissenters Justices Joseph Bradley and Stephen Field argued that the Fourteenth Amendment protects the right to pursue an occupation free from unreasonable government interference.

91 See U.S. CONST. amend. XIV. In the Slaughter-House Cases a group of butchers argued that a highly corrupted legislature in Louisiana adopted a law granting an economic monopoly without obvious public policy reasons. As a result, the butchers claimed that such law violated their occupational freedom. Even though the Court did not side with the butchers, the path was open for lawyers to deploy the Fourteenth Amendment to protect individual rights as a substantive due process guarantee embedding the principle of laissez-faire against economic legislation in Constitutional interpretation. Robert McCloskey, supra note 65 p.79.

92 See Duncan Kennedy, The Rise and Fall of Classical Legal Thought (1972).

${ }^{93}$ Robert McCloskey, supra note 65 at 88 showing how in Allgeyer v. Louisiana, 165 U.S. 578 in 1897 for the first time the Court invalidated a state law violating of liberty of contract.

${ }^{94}$ See Lochner v. New York, 198 U.S. 45 (1905) in which the Supreme Court held that a New York law limiting the working hours for bakers violated the Fourteen Amendment of the U.S. Constitution. In his opinion, Justice Peckham held that in the absence of evidence that the hours law protected public health, or that the jobs of bakers was in need of adequate regulations due to health reasons, the New York law constituted an unjustified interference with individual liberty of contract 
Constitution should not embody any particular economic theory nor that general propositions should decide concrete case. ${ }^{95}$

In his review essay, Why read The Transformation of Europe today?, Komárek expresses skepticism about Weiler's characterization of European courts as catalysts for change. For Komárek, Transformation is an article "about Europe", but "embedded in the American culture of liberal legalism that had been dominant at law schools in the United States until the mid-1980s". In particular, it "exhibits the trust in courts (especially the ECJ) similar to that of [American] legal liberals". ${ }^{96}$ This proposition led Weiler to overestimate the transformative power of European courts as detached from the socio-economic struggles dividing the Community along the North-South and later on, the East-West cleavage.

Far from playing an "exalted role" in the integration of EU law, Komárek argues that the European courts of the 1960s and 1970s were nothing more than institutional players, engaged in mundane, bureaucratic tasks: "There was nothing mystical or religious about them", he concludes. While we agree with Komarek's view, our task is to stress how Weiler's communitarian philosophy, focusing on popular sovereignty and the lack of a European demos, was struggling with figuring out ways for a Community as legitimated by its people. ${ }^{97}$ Living in the U.S. under the legacy of the Rehnquist Court, Weiler was not committed, as Stein was, to the form of U.S. constitutional law interpretation that was espoused by "his" U.S. Supreme Court. To the contrary, he distanced himself from the Rehnquist Court and avoided reference to contemporary state rights' doctrines when he addressed U.S.-style judicial federalism.

2. Downplaying the State Rights' Jurisprudence of the Rehnquist Court

Indeed, during the time period when Weiler was invoking a liberal legalist image of the ECJ and judicial federalism as a way to resolve institutional competence conflicts without engaging with the underlying

${ }^{95}$ Id. 89 showing how by 1917, the Supreme Court upheld labor reforms including workers' compensation laws and minimum wages and hours for all industrial workers, that severely undermined the doctrine of freedom of contract.

${ }^{96}$ See Jan Komárek, European constitutionalism: Towards an 'ideologycritique' (paper on file with the author).

${ }^{97}$ See Joseph H. Weiler, Europe's Sonderweg (Harvard Jean Monnet working paper 2001) and for a response see Peter

L. Lindseth, Delegation is Dead, Long Live Delegation: Managing the Democratic Disconnect in the European MarketPolity, in Good Governance In Europe's InTEGrated MARKet (Oxford University Press, 2002). 
political economy implications of federal adjudication, the Rehnquist Court was transforming U.S. federalism. The Rehnquist court was reinterpreting states' rights in ways that were strongly opposed by liberals and praised by conservatives also looking at Europe as a model for states' rights. ${ }^{98}$ In the same year that Weiler published Transformation, David Day described the U.S. Supreme Court in unabashedly political terms:

[T] he concept of federalism is a major doctrinal concern of the Rehnquist Court. After all, on the political level federalism has had close attachment to the Republican party and its recent domination of the Presidency. On the level of judicial doctrine, the modern federalism concept has provided a supportable and convenient vehicle for the conservative retrenchment of various constitutional doctrines. ${ }^{99}$

The Rehnquist Court used its power of judicial review to strike down a federal law designed to regulate gun possession in school zones, ${ }^{100}$ concluded that the federal government could not compel State officers to administer background checks on prospective handgun owners, ${ }^{101}$ and ruled unconstitutional a law that provided a federal civil remedy for gender-based violence, arguing that Congress' act threatened "to completely obliterate the Constitution's distinction between national and local authority ... "102.

As scholars of U.S. constitutional law and EU law, the most glaring omission we find in most European legal scholarship on U.S.-style judicial review are the many instances when U.S. courts failed to protect minorities from the tyranny of the majority. The U.S. Supreme Court has suffered its fair share of crises of legitimacy, many of which have been precipitated by controversial judgments involving race relations and state rights. The Dred Scott Court endorsed slavery, the Plessy Court sided with racial segregationists

${ }^{98}$ See Richard H. Fallon, The 'Conservative' Paths of the Rehnquist Court's Federalism Decisions, 69 U. Chi. L. Rev. 429, (2002). Ernest A. Young, The Rehnquist Court's Two Federalisms, 83 Texas Law Review 1-165 (2004) Ernest A. Young, What Can Europe Tell Us About the Future of American Federalism?, 49 Arizona State Law Journal 1109-1140 (2017).

${ }^{99}$ David S. Day, The Rehnquist Court and the Dormant Commerce Clause Doctrine: The Potential Unsettling of the Well-Settled Principles, 22 U. Tol. L. Rev. 675, (1991).

${ }^{100}$ United States v. Lopez, 514 U.S. 549, 549 (1995) (holding that the “Gun Free Zone Act of 1990" exceeded Congress' authority under the commerce clause).

${ }^{101}$ Printz v. United States, 521 U.S. 898, 933(1997).

102 United States v. Morrison, 529 U.S. 598, 615 (2000). 
and white supremacy ideology. These, and other decisions that comprise the so-called "anti-canon" of U.S. constitutional law, will remain blights on the institution for as long as it exists. To take just one particularly egregious example, consider Dred Scott, which is broadly understood among U.S. constitutional scholars and political scientists as the nadir of the U.S. Supreme Court's legitimacy. ${ }^{103}$ The legacy of Dred Scott legacy still haunts the Court to this days. In Obergefell v. Hodges, ${ }^{104}$ the Court held that the fundamental right to marry is guaranteed to same-sex couples by both the Due Process Clause and the Equal Protection Clause of the Fourteenth Amendment. In his dissent, Chief Justice Roberts accused the majority of failing to uphold the principle of judicial restraint, leaving such decisions to the legislative branch or to the states, just as it had failed, with disastrous consequences, in Dred Scott.

Legitimacy is a precious commodity for the "least dangerous branch". ${ }^{105}$ Its independence is precariouscontingent on the support, or at a minimum, the assent, of the public and the other branches. It is also fallible in entrenching economic inequalities and failing to grapple with racial capitalism. At times it has risen to the occasion, boldly protecting minority rights and fundamental values, but such task depending on the judicial elites in power and the socio-economic struggles has not always proved capable of carrying out the august role that Cappelletti and Weiler have assigned to judicial review.

\section{The Adverse Consequences of Europe's Dominant Constitutional Paradigm}

The failure to grapple with racial capitalism as racial differentiation and subordination in capitalist societies created an inadequate framework to address Europe's post-war colonial legacy. Indeed, such a reckoning was to European politicians and scholars alike, almost antithetical to the axiomatic fiction that Community law was created from a tabula rasa after World War II. In truth, Europe's economy was solidly grounded in racial capitalism - the notion that racial differentiation would start in the West where the fabrication of whiteness began at the same time that capitalism emerged so that the two produced "racial

${ }^{103}$ There is, however, a small body of revisionist literature that argues that the decision was a centrist opinion. See, e.g., Mark A. Graber, Desperately Ducking Slavery: Dred Scott and Contemporary Constitutional Theory, 14 CONST.

Comment 271 (1997); Mark A. Graber, Dred Scott as a Centrist Decision, 83 NCL ReV. 1229 (2004). 104576 U.S (2015).

${ }^{105}$ In Federalist 78, Alexander Hamilton provided a very convincing picture of the federal courts as institutions without "will" and composed of a body of independent judges, professionally trained with life-tenure appointments. 
capitalism", a system able to justify slavery, violence and imperialism. ${ }^{106}$ This is because, as Cedric J. Robison explains, at the very same times that European labor was "herded into a newly formed industrial order," African labor was globalized by the slave trade and incorporated in modern forms of production through racial subordination and exploitation. ${ }^{107}$

1. The Suppression of Racial Capitalism in European Constitutionalism

International lawyers have shown how racial capitalism allowed the Spanish crown to appropriate and sell Africans though the Atlantic slave trade. ${ }^{108}$ The literature produced by radical black Marxists since the 1950s is abundant and re-tells a story of the industrial revolution and the rise of nineteenth century bourgeoisie through the lens of racial capitalism. ${ }^{109}$ More recently legal historians have carefully shown how the wealth accumulated through slave labor in cotton and tobacco industries during the industrial revolution was capitalized and securitized in the New York and London stock exchanges. ${ }^{110}$

But rather than view this process as racial capitalism, the European founding fathers addressed it as part of their strategy to promote African economic development. The Schuman declaration of May 9, 1950, the founding document of the Coal and Steel Community, ends not only with the need to secure peace but also with the following sentence:

${ }^{106}$ See Robin D.G. Kelly, Foreword, Cedrick J. Robison, Black MarXism, The Making OF THE Black Radical TRADITION, (2000 edition).

${ }^{107}$ Id. at XIV.

${ }^{108}$ See Liliana Obregon, Empire, Racial Capitalism and International Law: The Case of Manumitted Haiti and the Recognition Debt, 31 Leiden Journal of International Law p. 597 (2018); Marti Koskenniemi, Empire and International Law: The Real Spanish Contribution, 61 University of Toronto Law Journal p. 36 (2011); ANTONY ANGHiE, IMPERIALISM, SOVEREIGNTY AND THE MAKING OF INTERNATIONAL LAW (2005).

109 Cedric J. Robinson and Robin D. G. Kelley Black MarXism: The Making of the Black Radical Tradition (2000) and Cedric J. Robinson: On Racial Capitalism, Black Internationalism, and Cultures of Resistance (Black Critique) (Cedric J. Robinson and H. L. T. Quan eds. 2019). W. E. B. Du Bois, Black Reconstruction in America: An Essay TOWARd a History of the Part Which Black Folk Played in the AtTempt to Reconstruct Democracy in AmERICA, 1860-1880 (1935).

110 Edward E. Baptist, The Half Has Never Been Told: Slavery and the Making Of AMerican CAPitalism (2014); SVen Beckert, Empire of CotTon: A Global History (2015). 
"With increased resources Europe will be able to pursue the achievement of one of its essential tasks, namely, the development of the African continent."

Rather than openly engaging with racial capitalism as a central reason for the exploitation of the African continent, the notion of how Europe should contribute to "African development" remerges today in the Commission's Trade for All agenda. ${ }^{12}$ The document effectively dismisses racial capitalism and the trade and migration effects of its colonial legacy. ${ }^{113}$ The newly formed Commission committed to promoting a European Way of Life appears unprepared to acknowledge Europe's role in promoting racial capitalism and its link to the rise of right-wing populist leaders with xenophobic traits in Hungary, Poland and Italy. ${ }^{114}$ The idea that Europe's colonial past justifies more generous migratory policies or redistribution through trade agreements with Europe's former colonies enjoys little to no political support. To the extent that race remains on the agenda, politicians and scholars confine it, implicitly, to trade agreements ${ }^{115}$ and policies to address illegal immigrants at the borders. ${ }^{116}$

The relationship between racial structures and the accumulation of wealth and power in Europe attracts relatively little attention in European law scholarship as well. The few exceptions include Eddie BruceJones, who has linked institutional racisms to Europe's colonial past, ${ }^{117}$ Iyiola Solanke, who has traced the deeper psychological roots of racial discrimination to theories of stigma, ${ }^{118}$ and scholarship that has

${ }^{111}$ See Robert Schuman, Schuman Declaration of May 9, 1950.

112 See Trade for All. The New Trade and Investment Strategy (2015) https://ec.europa.eu/trade/policy/in-focus/newtrade-strategy/

113 See Walter Rodney, How Europe UnderdeVeloped Africa (1972).

114 See Kim Lane Scheppele, Autocratic Legalism, 85 UnIV. OF CHICAGo L. REV. 545 (2018).

${ }^{115}$ See Daniela Caruso, Non-Parties: The Negative Externalities of Regional Trade Agreements in a Private Law Perspective, 59 Harvard International Law Journal 389 (2018); Daniela Caruso and Joanna Geneve, Melki in Context: Algeria and European Legal Integration, in BILL DAVIES AND FERNANDA NiCOLA EDS,

EU LAw STORIES: CONTEXTUAL AND CRITICAL HistORIES OF EUROPEAN JURISPRUDENCE

${ }^{116}$ See E. Tendayi Achiume, The Postcolonial Case for Rethinking Borders, Dissent (Summer 2019).

117 See EdDiE BRUCE-JONES, RACE IN THE SHADOW OF THE LAW (2016).

118 See Jacqueline Gehring, Hidden Connections: Citizenship and anti-discrimination policy in Europe in CitiZENSHIP POLICIES IN THE AGE OF DIVERSITY: EUROPE AT THE CROSSROADS (RICARD ZAPATA-BARRERO ed. 2009) and Claudia Kania Roma Communities in the EU Continue to Lack Access to Equal Education Opportunities 
shown how racism and ethnic differentiation are deeply entrenched in Europe's treatment and stereotyping of Roma population throughout the Union. ${ }^{119}$ Approaching the topic from a comparative perspective, some scholars have noticed how Critical Race Theory, which has blossomed in U.S. law schools since the 1980s, has faced stiff resistance in European law scholarship. Mathias Möschel has linked this outcome in European scholarship to a "double displacement" entailing the fact that the colonies remain outside the European territory and that racism, in the form of antisemitism, has been formally outlawed in the continent since the Holocaust. ${ }^{120}$ At the formal level, antisemitism is harshly rejected by governments and constitutional courts, yet the resurgence of antisemitism, racism and xenophobia in Europe is on the rise, especially fueled against Roma, immigrants, and non-white individuals.

\section{Shortcomings of EU Anti-Racist Legislation}

In 2000, the EU adopted its first piece of anti-racist legislation: Directive 2000/43, ${ }^{121}$ commonly known as the Race Equality Directive. It prohibits discrimination on grounds of race and ethnic origin, in, among other areas, employment and access to goods and services. Shortly thereafter, the EU adopted a second piece of legislation, Directive 2000/78, ${ }^{122}$ also known as the Employment Equality Directive. This directive extends anti-discrimination protections to more grounds-religion or belief, disability, age and sexual orientation—-but applies only to the field of employment.

Among the protected grounds covered under EU law, race discrimination was the primary concern of EU legislators. In fact, it is probably not an overstatement to say that the fate of anti-racist legislation was a prerequisite

(April 10, 2017) http://blogs.cuit.columbia.edu/rightsviews/2017/04/10/roma-communities-in-the-eu-continue-tolack-access-to-equal-education-opportunities/

\footnotetext{
119 See Iyiola Solanke, Discrimination as Stigma: A Theory OF AnTi-discrimination LaW (2016)

120 See Mathias Moschel, Lawyers and Race: Critical Race TheOry From the United States to Europe (2014).

${ }^{121}$ Council Directive 2000/43/EC of 29 June 2000 implementing the principle of equal treatment between persons irrespective of racial or ethnic origin, OJ L 180, 19.7.2000

122 Council Directive 2000/78/EC of 27 November 2000 establishing a general framework for equal treatment in employment and occupation, OJ L 303, 2.12.2000.
} 
for EU legislation covering all other grounds. Most accounts of the origins of Directive 2000/78 describe it as "riding in the wake" or "on the coattails" of the momentum produced by the Race Equality Directive. And yet, since the adoption of the Race Equality Directive only three judgments that address racial discrimination have reached the ECJ. ${ }^{123}$ Despite advances in many of the other "new" grounds, ${ }^{124}$ there appears to be an unwillingness or inability to enlist domestic courts to refer questions to the ECJ on race.

Early on, scholars like Daniela Caruso pointed out the limits of positive action in the EU due to historical and conceptual underpinnings of the myth of identity blindness, especially in French Law. ${ }^{125}$ More recently, Mathilde Cohen's interview-based study of the French judiciary strongly suggests that many French public officials are wary of even entertaining the possibility that race could play a role in how individuals are treated in society. ${ }^{126}$ It is not difficult to imagine why the Race Equality Directive would

${ }^{123}$ As will be well-known to most readers, the case-law of the ECJ develops primarily through the preliminary reference procedure (Art. $267 \mathrm{TFEU}$ ) — a process by which Member States pose questions regarding the proper interpretation of EU law to the ECJ. We do not mean to suggest that the ECJ's limited jurisprudence on racial discrimination is the result of a strategic decision on the part of the Court to avoid rulings on this topic. Rather, the stunted growth of the ECJ's case-law is mainly due to small number of preliminary references that it has received from Member State courts. See Mathias Möschel, 17 Years of Race Equality Directive: A Mitigated Balance, In UladzISLAU BELAVUSAU, EU Antidiscrimination Law Beyond Gender 141, 154 (Kristin Henrard eds., 2018) (arguing that the only preliminary references that deal with the substantive aspects of the directive so far are Feryn, CHEZ and Huskic); see also European Union Agency for Fundamental Rights, The RACIAl EQuality DiReCtive: ApPliCATION AND Challenges 19-24 (Luxembourg, Publications Office of the European Union, 2012).

124 The Equality Law: A New Generation dataset, shows that the most active of the "new" grounds has been in the field of age discrimination. Available at: https://equalitylaw.eui.eu/. On recent advances in the field of EU disability rights, see Jeffrey Miller, The European Disability Rights Revolution, 1 EUROPEAN L.R. 66-87 (2019).

${ }^{125}$ See Daniela Caruso, Limits of the Classic Method: Positive Action in the European Union after the New Equality Directives, 44 Harvard Int'1 L. J. 331, 367-369 (2001)

${ }^{126}$ See Mathilde Cohen. Judicial Diversity in France: The Unspoken and the Unspeakable, 43 LAW AND SOCIAL INQUIRY 1542, 1551 (2018) (“Ann Laura Stoler . . . has coined the expression colonial aphasia to describe French social scientists' difficulty in speaking about France's colonial past and neocolonial present. I noticed a comparable aphasia among French magistrats with respect to race and ethnicity. Some respondents simply refused to engage with the issue, remaining speechless, others attempted to circumvent it by answering a different question, and still others used a variety of euphemisms to designate racial and ethnic minorities without naming them explicitly."). 
be rarely invoked before a judiciary that "not only refuse[s] to name races and ethnicities, but also denie[s] the legitimacy of these categories." 127

Two recent rulings, $A$ chbita, ${ }^{128}$ and the case that joined to it, Bougnaoui, ${ }^{129}$ illustrate the reluctance of the ECJ to confront racial discrimination head-on. In fairness to the court, neither case was brought as race discrimination case, although they certainly could have become one without too much interpretative stretch. ${ }^{130}$ Acbbita involved a Muslim woman who was instructed not to wear a hijab (headscarf) because it violated the employer's neutrality policy. The ECJ sided with the employer, ruling that its interest outweighed Achbita's. As AG Kokott forthrightly stated in the introduction to her opinion, the case came before the court during difficult times:

There is no need to highlight here the social sensitivity inherent in this issue, particularly in the current political and social context in which Europe is confronted with an arguably unprecedented influx of third-country migrants and the question of how best to integrate persons from a migrant background is the subject of intense debate in all quarters. ${ }^{131}$

It is heavily disputed whether the Court struck the correct balance in the current political climate between the defendant-business's interest in a secular workplace and Achbita's freedom of religious. ${ }^{132}$ Less frequently discussed, but we think equally worthy of consideration, are the factors that led the plaintiffs to avoid framing the legal matter in terms of race discrimination. ${ }^{133}$

${ }^{127}$ See id. at 1552.

${ }^{128}$ Case C-157/15, G4S Secure Solutions (2017)

${ }^{129}$ Case C-188/15, Bougnaoui and ADDH (2017).

${ }^{130}$ See Mathias Möschel, Race discrimination and access to the European Court of Justice: Belov (1433 - 1450$)$ Vol. 5, Issue 5 Common Market Law Rev. (2013).

131 Case C-157/15, G4S Secure Solutions, Opinion of AG Kokott, para. 2. (2017).

132 See Joseph H. H. Weiler, Je Suis Achbita, 28 EuropeAn Journal of InTERnATIONAL LAW 989-1018 (2017).

133 See Ibram X. Kendi How to Be an Antiracist (2019). 


\section{Conclusion}

We share Matej Avbelj's intuition that the partial reception of U.S. constitutionalism has misled scholarship on European legal integration. ${ }^{134}$ At crucial moments in the intellectual history of EU law, this partial reception served a strategic purpose for scholars of legal integration. It provided the conceptual framework they needed to promote European constitutionalism, buttressed by an ostensibly politically neutral, supranational judicial review power for the ECJ. In Stein's scheme, reflecting on the successful legacy of the Warren court, ${ }^{135}$ U.S. constitutionalism was a promising model to strengthen the Community's supranational constitutional project. In the works of Weiler and Cappelletti, judicial review became a normatively appealing and politically neutral legal tool of federal integration that ignored the near-concurrent revamping of states' rights under the Rehnquist Court. But this partial reception also underplayed the United States' politically contested judicial history and its roots in racial capitalism. ${ }^{136}$

In European law scholarship the comparison with a "U.S.-inspired constitutionalism" has often been deployed as an ahistorical and liberal legalist narrative of judicial review and federalism that has been molded to fit integrationist agendas. ${ }^{137}$ This selective reception of U.S. constitutionalism has set aside national resistances, created self-defeating expectations and most importantly blunted the legal tools necessary to address racial subordination and economic exploitation in EU law.

Today it is especially important to foreground the darker legacies of U.S. constitutionalism and their many analogues in EU law instead of expelling them from the European constitutional heritage. ${ }^{138}$ The

${ }^{134}$ See Matej Avbelj, The Pitfalls of (Comparative) Constitutionalism for European Integration, (March 1, 2008), https://ssrn.com/abstract=1334216.

${ }^{135}$ See Earl Warren and the Warren Court. The Legacy in American and Foreign Law (Harry N. Scheiber ed. 2007).

${ }^{136}$ In this context the legacy of some of the most infamous decisions based on race differentiation to affirm racial segregation and discrimination, did not feature in the U.S.-European comparison Dred Scott v. Sandford 60 U.S. 393 (1857); Plessy v. Ferguson, 163 U.S. 537 (1896) (The majority upheld state-imposed racial segregation and Justice Brown held that separate treatment did not imply the inferiority In his dissent Justice Harland argued that the Constitution was color-blind).

${ }^{137}$ See Gunter Frankenberg, Comparative Constitutional Studies: Between Magic and Deceit 112 (2018).

${ }^{138}$ See Darker Legacies of Law in Europe. The Shadow of National Socialism and Fascism over Europe and its Legal Traditions (Christian Joerges AND NAVRAJ Singh GHaLeigh, eds. 2003); 
project of European legal integration is now more important than ever, but it will not survive unless it confronts its own structural flaws. "Fortress Europe" has created deep inequalities in the EU-African trade relationship, and these economic inequalities have returned to haunt Europe with unstoppable migratory fluxes. Market integration, as enforced by the ECJ in the name of free movement, has produced ambivalent distributive effects. ${ }^{139}$ And the EU's management of the sovereign debt crisis since 2010 has seriously undermined certain states' ability to sustain social safety-nets, ${ }^{140}$ and duly receive migrants. ${ }^{141}$ In crafting a new constitutional paradigm, lawyers, judges, and scholars must now be especially wary of apolitical comparison without underlying socio-economic and racial capitalism implications.

139 See Fernanda G. Nicola, Transatlanticism: Constitutional Asymmetry and Selective Reception of U.S. Law and Economics in the Formation of European Private Law, 16 CARDOZO J. INT'L \& COMP. L. 87 (2008).

140 See Philomila Tsoukala, P. (2020). Post-Crisis Economic and Social Policy: Some Thoughts on Structural Reforms 2.0. In F. Bignami (Ed.), EU Law in Populist Times: Crises and Prospects (pp. 67-90)

${ }^{141}$ Carlson, Melissa; Jakli, Laura; Linos, Katerina, Refugees Misdirected: How Information, Misinformation, and Rumors Shape Refugees' Access to Fundamental Rights 57 Va. J. Int'l L. 539 (2018) 
Author(s): Jeffrey Miller \& Fernanda Nicola

Title: The Failure to Grapple with Racial Capitalism in European Constitutionalism iCourts Working Paper, No. 201, 2020

Publication date: 14/July/2020

URL: http://jura.ku.dk/icourts/working-papers/

(C) Author

iCourts Working Paper Series

ISSN: 2246-4891

Jeffrey Miller is an assistant professor of business at Gallaudet University (Washington DC, USA) and a project manager at the Academy of European Law, European University Institute (Florence, Italy).

Email: jeffrey.miller@eui.eu

Fernanda Nicola is Professor of Law at American University, Washington College of Law, Director of the Program of International Organizations, Law and Development; Permanent Visiting Professor at iCourts

Email: fnicola@american.edu

The iCourts Online Working Paper Series publishes pre-print manuscripts on international courts, their role in a globalising legal order, and their impact on politics and society and takes an explicit interdisciplinary perspective.

Papers are available at http://jura.ku.dk/icourts/

iCourts

- The Danish National Research Foundation's Centre of Excellence for International Courts The Faculty of Law

University of Copenhagen

Karen Blixens Plads 16

2300 Copenhagen S

E-mail: icourts@jur.ku.dk

Tel. +453532 2626 